\title{
ANALISIS TAX PLANNING UNTUK EFISIENSI PAJAK PENGHASILAN (PPh ) PASAL 21 PADA PT. TRINITY SUKSES
}

\author{
Laura Sumual ${ }^{1}$, Inggriani Elim ${ }^{2}$, Sherly Pinatik ${ }^{3}$ \\ 1,2,3 Jurusan Akuntansi, Fakultas Ekonomi dan Bisnis, Universitas Sam Ratulangi, Jl. Kampus Bahu, Manado, \\ 95115, Indonesia \\ E-mail : sumuallaura@gmail.com
}

\begin{abstract}
Income tax is a tax collected on the tax object on his income. The purpose of the government that intends to maximize revenue from the tax sector is in fact contrary to the objectives of tax payers, where taxpayers try to streamline their tax burden so as to obtain greater profits in order to prosper their owners and continue the survival of their companies. Done by the company, one of which is by planning income tax especially Income Tax 21. The purpose of this study is to analyze the application of tax planning to corporate income tax, whether it is in accordance with the regulation of the Director General of Tax Number PER-31 /PJj / 2009 and Llaw no. 36 of 2008, and how the company utilizes tax regulations for planning taxes on corporate income tax. Objects that are subject to income tax are income from a person for work or business, agency or business form. This research is a descriptive study that compares and describes the state of an object of research in this case PT. Trinity sukses manado, by processing data and then comparing the results with the theory obtained. The results of this study are that the company has not carried out tax planning efficiently.
\end{abstract}

Keywords: income tax 21; tax planning; efficiency; tax payers; busniess entity

\section{PENDAHULUAN}

Pajak penghasilan merupakan pajak yang dipungut pada obyek pajak atas penghasilannya. Pajak penghasilan akan selalu dikenakan terhadap orang atau badan usaha yang memperoleh penghasilan di Indonesia. Salah satu pajak yang sering mengalami perbaikan, penyesuaian dan perubahan adalah $\mathrm{PPh}$ pasal 21. $\mathrm{PPh}$ pasal 21 merupakan $\mathrm{PPh}$ yang dikeluarkan atas penghasilan berupa gaji, upah, honorarium, tunjangan dan pembayaran lainnya sehubungan dengan pekerjaan atau jabatan, jasa dan kegiatan lainnya yang dilakukan oleh wajib pajak orang pribadi dalam negeri.

Tujuan pemerintah yang bermaksud untuk memaksimalkan penerimaan dari sektor pajak pada kenyataannya bertentangan dengan tujuan dari wajib pajak, dimana wajib pajak berusaha untuk mengefisienkan beban pajaknya sehingga memperoleh keuntungan yang lebih besar dalam rangka untuk mensejahterakan pemiliknya dan melanjutkan kelangsungan hidup perusahaannya. Oleh karena itu, penting bagi penulis membahas perencanan pajak penghasilan pasal 21 untuk membantu perusahaan berupaya mengefisienkan biaya yang dikeluarkan sehingga operasional perusahaan dapat berjalan lancer serta sesuai dengan ketentuan perpajakan..

PT.Trinity Sukses Manado merupakan salah satu perusahaan yang bergerak dibidang jasa pengadaan barang dan jasa. PT.Trinity Sukses Manado dipilih sebagai objek yang diteliti oleh penulis dikarenakan PT.Trinity Sukses Manado tidak terlepas dari kewajiban membayar pajak, yang meliputi Pajak Penghasilan. Perencanaan pajak bagi PT. Trinity Sukses Manado dimaksudkan untuk mengefisienkan jumlah biaya atau beban pajak yang akan diserahkan kepada pemerintah.

Berbagai penelitian tentang perencanaan pajak telah dilakukan oleh beberapa peneliti sebelumnya antara lain Dumayanti, C (2009) dalam penelitian yang berjudul 
"Analisis Penerapan Tax Planning Atas Biaya Kesejahteraan Karyawan Pada PT. Perkebunan Nusantara IV (Persero) Medan". Penelitian ini menjelaskan bahwa PT Perkebunan Nusantara IV (Persero) Medan telah berupaya menerapkan perencanaan pajak dengan baik, yaitu dengan memaksimalkan biaya-biaya kesejahteraan karyawan yang dapat mengurangi penghasilan bruto perusahaan untuk meminimalkan beban pajaknya tanpa melanggar undangundang yang berlaku.

Sebagai sumber dana yang diperlukan untuk menyelenggarakan pemerintahan dan membiayai pembangunan, penerimaan pajak akan terus-menerus dimaksimalkan oleh pemerintah. Khususnya pajak penghasilan yang dikenakan kepada orang pribadi, badan dan bentuk usaha tetap atas pengasilan sehubungan dengan pekerjaan atau jabatan, jasa, dan kegiatan dari pemotong pajak atau lebih dikenal dengan PPh pasal 21.

\section{TINJAUAN PUSTAKA}

Akuntansi Pajak.Menurut Muljono, D (2015:2), akuntansi pajak adalah bidang akuntansi yang berkaitan dengan perhitungan perpajakan, yang mengacu pada peraturan, undang-undang dan aturan pelaksanaan perpajakan. Prinsip-prinsip yang diakui dalam akuntansi perpajakan meliputi : kesatuan akuntansi, kesinambungan, harga pertukaran yang objektif, konsistensi, konservatif. Fungsi akuntasi pajak adalah mengolah data kuantitatif untuk menyajikan laporan keuangan yang memuat perhitungan perpajakan yang kemudian akan digunakan sebagai pertimbangan pengambilan keputusan. Tujuan kualitatif dalam akuntansi pajak adalah : relevan, dapat dimengerti, daya uji, netral, tepat waktu, daya banding dan lengkap. Menurut UU No.28 Tahun 2007 tentang ketentuan umum dan tata cara perpajakan, pasal 1 angka 3 , badan adalah sekumpulan orang dan atau modal yang merupakan kesatuan baik yang melakukan usaha maupun yang tidak melakukan usaha yang meliputi perseroan terbatas, perseroan komanditer, perseroan lainnya, BUMN atau BUMD dengan nama dan dalam bentuk apapun, firma, kongsi koperasi, dana pensiun, persekutuan, perkumpulan, yayasan, organisasi massa, organisasi sosial poltik, atau organisasi lainnya, lembaga dan bentuk badan lainnya, termasuk kontrak investasi kolektif dan bentuk usaha tetap. Menurut Trisnawati E (2017:5), akuntansi pajak adalah akuntansi yang diterapkan sesuai dengan peraturan perpajakan. Akuntansi pajak merupakan bagian dari akuntasi komersial.Akuntansi pajak tidak memiliki standar seperti akuntansi komesial yang diatur dalam Standar Akuntansi Keuangan (SAK). Akuntansi pajak hanya digunakan untuk mencatat transaksi yang berhubungan dengan perpajakan. Dengan adanya akuntansi pajak, wajib pajak dapat dengan mudah menyusun SPT. Akuntansi komersial disusun dan disajikan berdasarkan Standar Akuntansi Keuangan (SAK). Namun untuk kepentingan perpajakan, akuntansi komersial harus disesuaikan dengan aturan perpajakan yang berlaku di Indonesia. Oleh karena itu jika terdapat perbedaan antara ketentuan akuntansi dengan ketentuan perpajakan untuk keperluan dan pembayaran pajak, maka undang-undang perpajakan memiliki prioritas untuk dipatuhi agar tidak menimbulkan kerugian material bagi wp yang ber bersangkutan. Akuntansi mengikuti beberapa pedoman yang dikeluarkan oleh lembaga yang berhubungan dengan itu. Menurut Horngren, et. Al (2010:9-11) ada lima prinsip akuntansi yang digunakan yaitu :

1. Konsep Kesatuan/Entitas (The Entity Concept).

Konsep yang paling dasar di dalam akuntansi adalah entitas. Entitas akuntansi adalah suatu organisasi atau suatu baagian dari organisasi yang terpisahkan dari organisasi lain atau suatu bagian dari organisasi lain dan individu-individu yang lain yang merupakan suatu unit ekonomi yang terpisahkan.

2. Konsep Keandalan (The Reliability Objective Principle). 
Catatan dan laporan akuntansi harus didasarkan atas data yang tersedian yang paling dapat diandalkan sehingga catatan dan laporan tersebut kan menjadi akurat dan berguna. Prinsip ini juga disebut prinsip objektivitas.

3. Konsep Biaya (The Cost Principle).

Prinsip biaya menyatakan bahwa aktivitas dan jasa yang diperoleh harus dicatat menurut harga aktualnya atau nilai historisnya.

4. Konsep Kesinambungan (The Going-Concern Concept).

Sebab yang lain mengapa aktivitas harus dicatat menurut harga perolehan konsep kesinambungan, yang menyatakan bahwa suatu entitas akan terus melakukan usahanya untuk masa yang tidak daapt ditetapkan atau diramalkan usahana untuk masa yang tidak dapat ditetapkan atau diramalkan di masa depan. Aktiva seperti perlengkapan, tanah, bangunan, peralatan dibeli untuk digunakan dalam usaha bukan untuk dijual kembali. Berdasarkan konsep kesinambungan, diasumsikan bahwa perusahaan akan terus menggunakan aktiva yang dimilikinya dalam melakukan aktivitas operasionalnya untuk mencapai tujuan mereka.

5. Konsep Kestabilan Moneter(The Stable Monetary Unit Concept).

Suatu peningkatan dalam harga disebut inflasi dan selama inflasi dollar hanya dapat membeli sedikit barang saja. Para akuntan mengasumsikan bahwa daya beli dollar adalah stabil. Konsep kesatuan moneter stabil ini adalah disebabkan dasar untuk mengabaikan adanya efek dari inflasi di dalam catatan akuntansi.

Perencanaan Pajak Penghasilan Pasal 21. Mengefisiensikan beban pajak yang masih dalam ruang lingkup perpajakan, yaitu memaksimalkan pengurangan. Perencanaan pajak ini, ditekankan pada pengolahan PPh pasal 21 yang lebih efisisen, sesuai dengan Peraturan Direktur Jenderal Pajak nomor PER-31/PJ/2009 tentang Petunjuk Pelaksanaan Pemotongan, Penyetoran dan Pelaporan Pajak Penghasilan 21 dan 26. Mematuhi segala ketentuan administratif yaitu, melakukan pelaporan SPT PPh masa dan tahunan tepat waktu dan melakukan penyetoran pembayaran pajak tepat waktu. Pelaporan SPT tepat waktunya dilakukan paling lambat 20 hari setelah masa pajak berakhir dan penyetoran dilakukan paling lambat 10 hari setelah masa pajak berkahir. Hal ini dilakukan untuk menghindari dari pengenaan sanksi-sanksi baik sanksi administrasi maupun sanksi pidana seperti bunga, kenaikan, denda dan hukuman kurungan atau penjara. Melakukan secara efektif segala ketentuan peraturan perundangan-undangan perpajakan seperti memaksimalkan pengurangan-pengurangan yang terdapat pada pasal 4 dan pasal 6 Undang-Undang nomor 36 tahun 2008.

Efisensi dan Efektifitas Pajak

a. Efisiensi Pajak

H.Emerson yang dikutip oleh Hasibuan (2014:243) mendefinisikan efisiensi merupakan perbandingan yang terbaik antara input (masukan) dan output. Halim,A ( 2014:166) menyatakan bahwa efisiensi ketetapan atau cara untuk mengelola pajak (tidak membuang biaya, kemampuan menjalankan tugas pemungutan dengan baik, penggunaan jumlah tenaga/bahanyang sesuai dengan standar) yang telah ditetapkan dan perbandingan antara inputdan output dalam suatu proses.

Efektivitas Pajak

Menurut Mardiasmo (2014:134) Efektivitas adalah ukuran berhasil tidaknya suatu organisasi mencapai tujuannya. Kegiatan operasional dikatakan efektif apabila proses kegiatan mencapai tujuan dan sasaran akhir kebijakan (spending wisely). Semakin besar kontribusi yang dihasilkan terhadap pencapaian tujuan atau sasaran yang ditentukan, maka semakin efektif proses kerja suatu unitorganisasi. Menurut H.Emerson yang dikutip oleh Hasibuan (2014:242) menyatakan bahwa efektivitas adalah pengukuran dalam arti tercapainya sasaran atau tujuan yang telah ditentukan sebelumnya. 
Sadeli, F (2011:18), laporan keuangan adalah laporan tertulis yang memberikan informasi kuantitatif tentang posisi keuangan dan perubahan-perubanannya, serta hasil yang dicapai selama periode tertentu.

Metode penghitungan $\mathrm{PPh}$ pasal 21

Menurut Pohan, C (2014:91), ada 3 metode yang bisa digunakan dalam perhitungan pajak penghasilan Pasal 21, yaitu :

Gross Method (PPh Pasal 21 ditanggung oleh karyawan)

Merupakan metode pemotongan pajak dimana karyawan menanggung sendiri jumlah pajak penghasilannya, yang biasanya dipotong langsung dari gaji karyawan yang bersangkutan.

Net Method (PPh Pasal 21 ditanggung oleh perusahaan)

Merupakan metode pemotongan pajak dimana perusahaan menanggung pajak karyawannya.

Sebagaimana dimaksud dalam Peratura. Dirjen Pajak Nomor PER-31/PJ/2009 Pasal 5 ayat (2) dan Pasal 8 ayat (1), Penghasilan yang dipotong PPh Pasal 21 dan/atau PPh Pasal 26 termasuk pula penerimaan dalam bentuk natura dan/atau kenikmatan lainnya dengan nama dan dalam bentuk apapun yang diberikan oleh bukan Wajib Pajak, Wajib Pajak yang dikenakan Pajak Penghasilan yang bersifat final; atau wajib pajak yang dikenakan Pajak Penghasilan berdasarkan norma penghitungan khusus (deemed profit). Selanjutnya pada Pasal 8 ayat 2 menegaskan bahwa Pajak Penghasilan yang ditanggung oleh pemberi kerja, termasuk yang ditanggung oleh Pemerintah, merupakan penerimaan dalam bentuk kenikmatan.

Gross-up Method (Tunjangan Pajak yang di gross up)

Merupakan metode pemotongan pajak dimana perusahaan memberikan tunjangan pajak yang jumlahnya sama besar dengan jumlah pajak yang akan dipotong dari karyawan. Perhitungan tunjangan pajak di formulasikan untuk menyamakan jumlah pajak yang akan dibayar dengan tunjangan pajak yang diberikan perusahaan terhadap karyawannya.

Menurut Sumarsan, T (2013:118), penyelundupan pajak merupakan pelanggaran terhadap undang-undang dengan maksud melepaskan diri dari pajak/mengurangi dasar penetapan pajak dengan cara menyembunyikan sebagian dari penghasilannya.

Suandi, E (2016:25), jenis-jenis perencanaan pajak dapat dibagi menjadi 2, yaitu :

1. Perencanaan pajak nasional (national tax planning)

2. Perencanaan pajak internasional (international tax planning)

\section{METODE PENELITIAN}

Jenis data yang dipergunakan dalam penelitian ini, yaitu:

1. Data Kualitatif, yaitu data yang disajikan secara deskriptif atau terbentuk uraian seperti :

sejarah singkat perusahaan, struktur organisasi dan job description, dokumendokumen, serta Undang-undang dan peraturan-peraturan yang berkaitan dengan $\mathrm{PPh}$ Badan.

2. Data Kuantitatif, yaitu data yang disajikan dalam bentuk angka-angka atau bilangan yang dapat dihitung dan dapat dibandingkan yang satu dengan yang lainnya. Datadata tersebut berupa daftar gaji pegawai tetap, penghitungan PPh Badan.

Sumber Data

Sumber data dalam penelitian ini, yaitu :

1. Data Primer, yaitu data yang diperoleh langsung oleh penulis dari objek penelitian dengan cara wawancara, dan data yang diambil dari perusahaan seperti daftar gaji pegawai tetap, perhitungan PPh Badan.

2. Data Sekunder, yaitu data yang berasal dari sumber atau pengamatan lain. Contohnya: buku-buku literatur yang digunakan sebagai acuan, jurnal penelitian, Undang-undang dan peraturan tentang PPh Badan serta data pendukung lainnya. 
Metode analisis data yang digunakan dalam penelitian ini adalah metode deskriptif, yaitu membahas masalah dengan cara mengumpulkan, menguraikan, menghitung, dan membandingkan suatu keadaan serta menjelaskan suatu keadaan sehingga dapat ditarik kesimpulan yang meliputi perencanaan pajak PPh Badan pada PT. Trinity Sukses Manado.

\section{HASIL PENELITIAN DAN PEMBAHASAN}

\subsection{Hasil Penelitian}

Rekonsiliasi Perhitungan Laba Rugi Komersial dan Fiskal dapat di jelaskan sebagai berikut:

1. Beban Personalia

Dalam unsur beban personalia terdapat biaya PPh pasal 21 atas gaji karyawan tetap yang semuanya ditanggung perusahaan. Pajak yang ditanggung perusahaan ini merupakan kenikmatan yang diterima oleh karyawan dan bukan merupakan penghasilan bagi karyawan yang bersangkutan sesuai dengan Pasal 9 ayat 1 huruf e dan Pasal 8 ayat 2 PMK Nomor 252/PMK.03/2008 menyatakan bahwa “. Koreksi positif dilakukan atas keseluruhan biaya tersebut karena bukan merupakan biaya fiskal dan bukan pengurang penghasilan bruto sebesar Rp. 16.192.930.

2. Beban Operasional Lainnya

Perusahaan mengeluarkan biaya untuk seragam karyawan.Atas pengeluaran biaya ini maka harus dilakukan koreksi fiskal positif.Hal ini karena biaya seragam yang dikeluarkan bukan untuk tujuan keselamatan kerja tetapi hanya untuk keseragaman kerja saja. Sesuai dengan aturan perpajakan yaitu pada pasal 9 ayat (1) huruf e UU $\mathrm{PPh}$ yang menyatakan bahwa pemberian natura dan kenikmatan yang merupakan keharusan dalam pelaksanaan pekerjaan sebagai sarana keselamatan kerja atau karena sifat pekerjaan tersebut mengharuskannya, seperti pakaian dan peralatan untuk keselamatan kerja, pakaian seragam petugas keamanan (satpam), antar jemput karyawan serta penginapan untuk awak kapal dan yang sejenisnya. Besarnya koreksi fiskal positif adalah Rp. 5.325.000.

3. Beban Non Operasional

Perusahaan harus melakukan koreksi fiskal positif atas biaya untuk jamuan tamu. Biaya ini tidak termasuk dalam Pasal 6 ayat (1) UU PPh karena tidak didukung oleh bukti-bukti yang memadai yang dapat memastikan bahwa biaya-biaya tersebut benar-benar berkaitan dengan kegiatan perusahaan untuk mendapatkan, menagih, dan memelihara penghasilan. Biaya jamuan tamu ini tidak dapat dijadikan pengurang penghasilan bruto karena biaya jamuan tamu tidak disertakan dengan daftar nominatif sehingga biaya tersebut dianggap tidak ada (fiktif) sebagaimana telah tercantum didalam Surat Edaran Direktur Jenderal Pajak No.SE-27/PJ.22/1986. Biaya ini di koreksi positif sebesar Rp.3.522.000.

4. Pajak Penghasilan Badan $\quad=25 \% \times(50 \% \times$ Penghasilan Kena Pajak)

$$
\begin{aligned}
& =25 \% \times(50 \% \times \text { Rp.665.404.930,-) } \\
& =\text { Rp. 83.175.616,- }
\end{aligned}
$$

\subsection{Pembahasan}

Rekonsiliasi Perhitungan Laba Rugi Komersial dan Fiskal Sebelum dan Sesudah Perencanaan Pajak dapat di jelaskan sebagai berikut:

Setelah perencanaan pajak dengan mengganti tunjangan makan dengan fasilitas makan bersama dan perusahaan memberikan tunjangan pajak yang jumlahnya sama besar dengan jumlah pajak yang akan dipotong dari karyawanatau menggunakan metode gross up, terjadi perubahan pada total PPh pasal 21 terutang yang sebelumnya Rp. 16.192.930,- menjadi Rp. 9.992.577,-. Tunjangan PPh 21 yang diberikan perusahaan kepada karyawan tetap merupakan biaya atau pengeluaran yang dapat dikurangkan pada penghasilan bruto perusahaan. Beban 
personalia yang sebelumnya Rp. 1.154.672.000,- dengan koreksi fiskal positif sebesar Rp. 16.192.930,- ,setelah perencanaan pajak maka beban personalia menjadi Rp. 1.148.471.647 tanpa koreksi fiskal positif, Rp.1.148.471.647 merupakan selisih dari Beban personalia sebelum perencanaan pajak sebesar Rp. 1.154.672.000,- dikurangiselisih PPh 21 terutang sebelum dan sesudah perencanaan pajak sebesar Rp. 6.078.948,- (Rp.16.192.930Rp.9.992.577). Perubahan pada beban personalia tersebut berdampak pada total beban fiskal untuk beban operasional dan non operasional perusahaan yang sebelumnya sebesar Rp. 3.370.468.070,- menjadi Rp. 3.383.460.647,- Beban pajak penghasilan badan yang sebelumnya sebesar Rp. 83.175.616,-(25\% x (50\% x Rp.665.404.930)) setelah perencanaan pajak menjadi Rp. 81.551.544.,- (25\% x (50\% x Rp.652.412.353)). Terjadi penghematan pajak PPh pasal 21 sebesar Rp. 6.078.948,-(Rp. 16.192.930 - Rp.9.992.577) dan penghematan pajak penghasilan badan sebesar Rp.1.624.072(Rp.83.175.616-Rp.81.551.544

Hasil penelitian ini dari Chirunnisa, D (2009) dalam penelitian yang berjudul "Analisis Penerapan Tax Planning Atas Biaya Kesejahteraan Karyawan Pada PT. Perkebunan Nusantara IV (Persero) Medan". bahwa PT Perkebunan Nusantara IV (Persero) Medan telah berupaya menerapkan perencanaan pajak dengan baik, yaitu dengan memaksimalkan biayabiaya kesejahteraan karyawan yang dapat mengurangi penghasilan bruto perusahaan untuk meminimalkan beban pajaknya tanpa melanggar undang-undang yang berlaku dan selaras dengan penelitian dari Rizky, A (2009) dalam penelitiannya yang berjudul "Penerapan Tax Planning PPh Pasal 21 Pada PT. Master Daya Utama Guna Pencapaian Tax Saving”. Hasil penelitian tersebut menjelaskan bahwa PT. Master Daya Utama belum optimal melakukan perencanaan pajak untuk meminimalkan beban pajak penghasilan walaupun perusahaan telah menerapkannya tanpa melanggar undang-undang yang berlaku. Persamaan dengan penelitian ini dan penelitian yang penulis lakukan adalah sama-sama melakukan perencanaan pajak $\mathrm{PPh}$ pasal 21 dengan mengefisienkan biaya PPh pasal 21 yang ditanggung perusahaan agar dapat menjadi biaya pengurang penghasilan bruto perusahaan. Namun terdapat perbedaan yaitu penelitian terdahulu tidak memasukkan data Rekonsiliasi Perhitungan Laba Rugi Komersial dan Fiskal.

\section{KESIMPULAN DAN SARAN}

\subsection{Kesimpulan}

Berdasarkan pembahasan yang telah dilakukan pada bab-bab sebelumnya, maka peneliti dapat menarik kesimpulan sebagai berikut :

Perusahaan telah melakukan penghitungan PPh pasal 21 karyawan tetap tahun 2018 sesuai dengan peraturan perpajakan yang berlaku dengan total PPh pasal 21 terutang sebesar Rp. 16.192.930,-

Perusahaan belum melakukan perencanaan pajak dengan efisiensi dan maksimal untuk mengefisiensikan biaya PPh Pasal 21 karyawan tetap yang seluruhnya ditanggung oleh perusahaan.

$\mathrm{PPh}$ pasal 21 karyawan tetap sebesar Rp. 16.192.930.- yang seluruhnya ditanggung oleh perusahaan menurut peraturan perpajakan biaya tersebut tidak diperkenankan menjadi pengurang penghasilan bruto perusahaan, sehingga laba perusahaan menjadi lebih besar yaitu Rp.665.404.930, -yang berdampak pula pada besarnya PPh Badan yang akan dibayar perusahaan sebesar Rp.83.175.616,-

\subsection{Saran}

Dalam kesempatan ini akan diberikan beberapa saran yang dapat diterapkan perusahaan dalam pelaksanaan perencanaan pajak, diantaranya adalah:

Sebaiknya perusahaan dalam perhitungan PPh pasal 21 yang terutang memasukkan tunjangan pajak yang dapat diperhitungkan dalam perhitungan pajak penghasilan perusahaan, sehingga perusahaan dapat menghemat pembayaran pajak penghasilan badan yang terutang. Pemberian 
tunjangan pajak, dari pihak karyawan akan lebih diuntungkan dalam membayar pajak penghasilan yang seluruhnya ditanggung perusahaan. Selain tunjangan pajak, dalam pelaksanaan perencanaan pajak perusahaan dapat memberikan tunjangan makan diganti dengan makan bersama.Bagi karyawan, tunjangan tersebut bukan merupakan penghasilan dan bagi perusahaan merupakan biaya.Perusahaan perlu melakukan perencanaan pajak yang efektifatas PPh pasal 21 sehingga dapat berpengaruh pada menurunnya PPh Badan yang akan dibayar oleh perusahaan.

\section{DAFTAR PUSTAKA}

Dumayanti, C. (2009). Analisis Penerapan Tax Planning Atas Biaya Kesejahteraan Karyawan Pada Sumatra

PT.Perkebunan Nusantara IV (Persero) Medan. Fakultas Ekonomi Universitas

Utara Medan. http://repository.usu.ac.id/handle/123456789/8812.

Hasibuan. (2014). Perencanaan Pajak. Edisi 4. Jakarta : Salemba Empat.

Halim, A. (2014). Perpajakan : Konsep, Aplikasi,Contoh,dan Studi Kasus. Jakarta : Penerbit Salemba Empat.

Horngren., \& Harrison. (2010). Akuntansi. Jilid 2. Edisi 7. Jakarta : Erlangga

Muljono, D. (2015). Akuntansi Pajak Lanjutan. Jakarta: Andi.

Mardiasmo. (2014). Perpajakan edisi revisi.Yogyakarta : Andi.

Peraturan Menteri Keuangan Nomor 252/PMK.03/2008. Petunjuk Pelaksanaan Pemotongan, Penyetoran dan Pelaporan Pajak Penghasilan Sehubungan dengan Pekerjaan, Jasa, dan Kegiatan Orang Pribadi.

Peraturan Dirjen Pajak Nomor PER-31/PJ/2009. Pedoman Teknisi Tata Cara Pemotongan, Penyetoran

Sehubungan

Dan Pelaporan Pajak Penghasilan Pasal 21 dan/atau Pajak Penghasilan Pasal 26

Dengan Pekerjaan, Jasa, dan Kegiatan Orang Pribadi.

Pohan, C. (2014). Strategi Perencanaan Pajak dan Bisnis. Jakarta : Gramedia Pustaka Utama.

Sadeli, F. (2011). Lika-Liku Strategi Keuangan Perusahaan Panduan Praktis Meningkatkan

Nilai Perusahaan. Jakarta: Penerbit Salemba Empat.

Sumarsa, T. (2013). Tax Review dan Strategi Perencanaan Pajak . Jakarta : Indeks.

Suandi, E. (2016). Perencanaan Pajak Edisi 6. Yogyakarta: Salemba Empat.

Trisnawati, E (2017). Akuntansi Perpajakan. Jakarta : Salemba Empat.

Undang-Undang Republik Indonesia Nomor 28 Tahun 2007. Tentang Perubahan Ketiga Atas Perpajakan.

Undang-Undang Nomor 6 Tahun 2007 tentang Ketentuan Umum dan Tata Cara

Lembar Negara Republik Indonesia Nomor 4740. Jakarta.

Undang-Undang Republik Indonesia Nomor 36 Tahun 2008. Tentang Pajak Perubahan Keempat Atas

Undang-Undang Nomor 7 Tahun 1983 tentang Penghasilan. Lembar Negara Republik

Indonesia Nomor 4893. Jakarta. 